BENCSIK Andrea - Renáta MACHOVÁ

\title{
ESÉLYEGYENLŐSÉG - ÉRTÉK \\ VAGY ILLÚZIÓ? - \\ DISZKRIMINÁCIÓ A MUNKAHELYEN
}

A tanulmány célja a diszkrimináció, ezen belül is a munkahelyi diszkrimináció vizsgálata. A témakör elméleti hátterének rövid bemutatása után egy vállalati példa szolgáltatja az alapot a valóságos történések megítélésére. A szerzók tanulmányukban felvázolták a hátrányos munkahelyi megkülönböztetés megnyilvánulásainak negatív hatásait a munkatársak viselkedésére, munkahelyi teljesítményére, egyúttal a vállalati sikerre. Az elméleti alapok bemutatása után egy kiválasztott vállalat teljes munkatársi állományát kérdezték meg kérdő́iv segítségével arról, hogy ốk maguk hogyan érzékelik a hátrányos megkülönböztetés megnyilvánulásait, és mit tesznek vagy nem tesznek a probléma kezelése érdekében. A tanulmány a vizsgálat eredményeit összegzi.

Kulcsszavak: alkalmazott, diszkrimináció, esélyegyenlőség, hátrányos megkülönböztetés

„Az egyetlen cél, amelynek érdekében jogos lehet egy civilizált közösség bármely tagjával szemben - akarata ellenére - erốszakot alkalmazni: mások sérelmének megakadályozása." (J. S. Mill)

A diszkrimináció kifejezés alatt a társadalom különböző közösségeiben fellépő, az egyént vagy egy adott csoportot érő igazságtalanságot értjük, mely mögött hátrányos megkülönböztetô jellemzók képezik a megítélés alapját. Bár a diszkrimináció megnyilvánulhat pozitív módon is, valamint nyílt vagy burkolt formában, vizsgálatunk szempontjából az elốbbi kap hangsúlyozott szerepet.

Már az emberiség fejlődésének kezdeteitôl megfigyelhető különböző emberi csoportok között létrejövő megkülönböztetés. Minden kor a maga vallási, politikai és jogi eszközeivel igyekszik kiküszöbölni ezt a helytelen magatartást, mind ez idáig sajnos sikertelenül. Az Európai Unió - számos intézkedésével, határozatával, szabályaival próbál akadályt gördíteni e negatív és elítélendő emberi magatartásforma további megnyilvánulásai elé (Szalai, 2011a). Saját tapasztalataink mellett ezért is tartottuk fontosnak, hogy megvizsgáljuk, hogyan jelentkezik a gazdálkodó szervezetek gyakorlatában a diszkrimináció jelensége, tesznek-e, és ha igen, mit, az illetékes vezetók a jelenség kiküszöbölésére. Úgy érezzük, hogy a XXI. században különösen nem elhanyagolható viselkedés, gondolkodásmód, hozzáállás változtatásáról kell gondoskodni ahhoz, hogy a társadalomban már a történelem kezdeti időszakában fejlôdésnek indult és mélyen beívódott jelenség megszüntethetô és felszámolható legyen. Ez a változás csak az emberek közötti kölcsönös összefogás, feltétel nélküli elfogadás és komoly erófeszítések segítségével lehetséges. A demokrácia alappillére, egyben elvárása, hogy megvalósuljon a teljes körú egyenlőség a társadalomban, s ez a vágy a XXI. században mindenekfeletti létjogosultságot kap.

A következókben egy rövid összegzését adjuk az esélyegyenlőséggel kapcsolatos törvényi szabályozás kialakulásának, és az abban megfogalmazottak alkalmazásának szükségszerúségéról.

\section{A diszkrimináció elméleti háttere}

„A diszkrimináció olyan megközelítést jelent, amely ésszerútlen különbségtételt vezet be az érintett alanyi jogok élvezetével összefüggésben. Ez a meghatározás három elemet rejt magában. Ezek a következók: a meg- 
különböztetés negatív hatása az érintett személyre, ez a hatás a különbségtételbôl ered, és a különbségtétel ésszerútlen, nem indokolható" (Kende, 2005: 275. o.).

A mindennapi életben érzékelhetô megnyilvánulási formái lehetnek például előítéletes beszéd, leírt szöveg, gúnyos viccek, gesztusok, helytelen közeledés, esetleg a közeledés hiánya, indokolatlan távolságtartás, csúfolódás, sốt megalázás (Gyulavári - Könczei, 2000).

A magyar állam európai uniós kötelezettségeinek eleget téve 2003-ban alkotta meg az egyenlő bánásmódról és az esélyegyenlóség előmozdításáról szóló 2003. évi CXXV. törvényt (Ebtv.), mely a kérdéskört átfogóan szabályozza, illetve 2005-ben létrehozta az egyenlő bánásmód követelményének érvényesülését ellenôrző intézményt, az Egyenlő Bánásmód Hatóságot.

A gyakorlati tapasztalatok szerint a diszkrimináció fajtái közül leggyakoribb a közvetlen diszkrimináció, amely legnagyobb számban a foglalkoztatás területén fordul elő, míg a védett tulajdonságok alapján osztályozva legtöbbször a nem, a fogyatékosság, valamint a nemzeti és etnikai kisebbséghez tartozás alapján történik hátrányos megkülönböztetés (http://www. antidiszko.hu/index.php?id=8).

Tanulmányunk célja elsôsorban a munkahelyi körülmények között megjelenó diszkrimináció eseteinek bemutatása, illetve a vizsgált vállalatnál előforduló konkrét problémák észlelésére tett intézkedések feltárása.

\section{A munkahelyi diszkrimináció}

A munkahelyi diszkrimináció lehet nyílt, de a legtöbb esetben épp azért nehéz azonosítani, mert rejtett és bonyolult áttételeken, összefüggéseken keresztül érzékelhetô. Olykor a megkülönböztető magatartás nem is szándékos, nincs konkrét alapja, mégis mélyen, rejtve a társadalomban él, s megjelenik a hétköznapi viselkedésben. Kertesi Gábor meghatározása szerint: „A munkaerópiacon akkor beszélhetünk diszkriminatív, megkülönböztetó munkáltatói viselkedésról, ha azonos termelékenységú (vagyis azonos „minőségư”) munkaerő́t a munkáltatók eltéró módon értékelnek" (Kertesi, 2001: 81. o.).

Ha összevetjük a magyar jogrendben meghatározott diszkriminatív elemeket az ausztrál kormány Fair Work Ombudsmanja (Fair Work Act, 2009) vagy az amerikai jog által meghatározott problémás területekkel, hasonló jellegú felsorolásokat találhatunk (http://www.law. cornell.edu/wex/employment_discrimination, 2013).

A magyar elvárások az uniós iránymutatásnak teljes mértékben megfelelnek, így az európai országokra érvényes szabályokkal összhangban született meg a diszkriminációra vonatkozó törvényünk.

\section{A megkülönböztetés vállalati szempontjai}

$\mathrm{Az}$ említett törvények, helyi szabályok, nemzeti rendelkezések mindent megtesznek annak érdekében, hogy ez az emberileg nehezen tolerálható viselkedés ne nyerjen teret. Mégis, a küzdelem bumeráng módjára okoz állandóan visszatérő problémát egyénnek és szervezetnek egyaránt. Legismertebb diszkriminációhoz vezetố tulajdonságok, melyek éreztetik hatásukat a vállalati gyakorlatban, a származás, fogyatékosság, vallási vagy világnézeti meggyőződés, szexuális orientáció, bizonyos, a munkavégzést nem befolyásoló egészségügyi problémák, politikai meggyőződés, szakszervezeti tagság. A Munka Törvénykönyvében még ennél szélesebb körú a szempontok listája, mégsem beszélhetünk teljesen kiegyensúlyozott múködésról ezen a területen (Debrecéniová, 2008).

Napjaink leginkább szembetúnő jelensége a vállalati gyakorlatban a fizetésekben és a magasabb pozíció elérési lehetôségeiben megnyilvánuló különbség. A nôk és a férfiak közötti valódi egyenlőség tulajdonképpen azon a tévhiten alapul, hogy az egyenlőség már a kommunizmus idején megvalósult. Ez azonban a legcsekélyebb mértékben sem fedi a valóságot. A formális egyenlóség ugyan létezett, ám a nók az „emancipált nô” modelljével azonosulva vállaltak lényegesen nagyobb terheket, mint férfi társaik. A diszkrimináció egyik fố forrásává lépett elô az az igény, hogy a nóket kettős funkcióban kívánták látni: anya szerepben és munkavállalóként. Egy uniós felmérés igazolni látta, hogy a 90-es években még mindig jóval magasabb az ugyanabban a munkakörben dolgozó férfiak fizetése, mint a hasonló szaktudással rendelkezô nóké (Štangová, 2011; Szalai, 2011b).

Az egyik leggyakrabban tetten érhetô probléma az alkalmazás és álláskeresés során tapasztalt hátrányos megkülönböztetések közül az életkor miatti diszkrimináció, ezt követi az etnikai és nem szerinti megkülönböztetés. Az etnikai megkülönböztetés szintén előkelő helyen áll, rengeteg kellemetlen tapasztalattal, mely esetünkben fóként a roma lakosságot érinti (Szuhay, 1999; Babusik - Adler, 2002).

A munkahelyi diszkrimináció új formája az életkor, a szexuális orientáció, a csökkent munkaképesség, a HIV/AIDS fertőzöttség, valamint az egészségkárosító életmód egyaránt. Szintén egy új jelenség az olyan gyakorlatok bevezetése, melynek révén a munkaadók kiszúrik azon személyeket, akiknek esetében „,genetikai hajlam" következtében valószínúsíthetô bizonyos betegségek kialakulásának lehetôsége (Štangová, 2011).

A diszkrimináció létezésének igazolása sokszor körülményes, pedig a jogi eljárás lefolytatásához a probléma létezésének bizonyíthatósága elengedhetetlen 
feltétel. Így nem csoda, hogy vizsgálataink során a nyilvánosságra kerülő eseteknél lényegesen több probléma fedezhetô fel a vállalatok életében, de azok nem kerülnek felszínre, vagy legalábbis nem lesz következményekkel járó ügy belólük (http://public.getlegal.com/ legal-info-center/employment-discrimination, 2008).

\section{A vállalati kultúra jelentốsége}

Az emberi erőforrás ma a vállalati élet meghatározó tényezôje, mely a legfontosabb eróforrásnak számít. A szervezet a környezet kihívásaira reagálva alakítja ki a rá jellemzó viselkedést, a szervezet tagjai által elfogadott és közösen alkalmazott hagyományokat, értékek, rituálék együttesét.

A szervezeti kultúrában jelennek meg azok a befolyásoló tényezók, melyek a diszkriminatív viselkedés jegyeinek tetten érését lehetôvé teszik. A gazdasági szempontú elemzések egyértelmúvé tették, hogy a diszkrimináció a vállalati stratégián keresztül a vállalati kultúrában jelenik meg (Világi, 2013).

Nem elegendő arra törekedni, hogy a különböző szabályzatoknak, törvényi előírásoknak eleget tegyen egy vállalat, a viselkedés meghatározó tényezőii, mint a kultúra, stratégia, vezetési stílus, legalább olyan jelentôs mértékben befolyásolják a diszkrimináció jelenlétét, mint a jogszabályi háttér.

A bemutatott elméleti alapok után kutatási kérdésként fogalmazódott meg:

- Gazdálkodó szervezetek esetében mennyire tapasztalhatók meg az elméletben bemutatott problémák?

- Az észlelt vagy a munkavállalók által jelzett problémák megoldására milyen vezetói reakciók érvényesülnek?

A következő fejezetben egy vállalati vizsgálat eredményeit mutatjuk be.

\section{A diszkrimináció megjelenése a vállalati gyakorlatban}

\section{A vizsgálat célja}

A kutatás célja, hogy bemutassa a vállalati érdekek kettősségét, nevezetesen a gazdaságosság, nyereségesség elérésének vágyát, valamint az emberi eróforrásokra vonatkozó jogi elő́írások, azok betartásának, betarthatóságának szemben állását.

A vizsgálat során a kutatás tárgya:

- Létezik-e a vállalati múködésben bármely, a fentiekben bemutatott diszkriminatív jellegú probléma?

- Amennyiben tapasztalható bármely területen diszkrimináció, az a vezetéstôl vagy a munkatársaktól származik?
- Történik-e bármilyen intézkedés, reakció a kellemetlen munkahelyi szituációk vagy hátrányos megkülönböztetés megszüntetésére, esetleg annak megelőzésére?

\section{A kutatás módszertana}

A felmérés elsôsorban kvantitatív módszer, nevezetesen kérdőíves felmérés alkalmazásán alapul. Ennek segítségével átfogó képet kaptunk egy nagyvállalat gyakorlatáról, problémáiról, az azokra adott vezetôi reakciókról. A kérdőív 16 kérdésból állt, melyek jellemzốen zárt típusúak voltak, de néhány esetben adtunk lehetôséget a saját vélemény szabad kifejtésére is.

A mintavételi egységet kizárólag a vizsgált vállalat alkalmazottjai alkották. A vállalat vezetésének beleegyezésével a kérdőívet az összes alkalmazotthoz eljuttattuk. A papíralapú 512 db kiosztott kérdőívből 318 értékelhetố került feldolgozásra.

A kérdőíves felmérés eredményeinek kiértékelése Excel táblázat és SPSS program segítségével történt.

A kvantitatív eredmények kiegészítése személyes megfigyelés és strukturált mélyinterjú technikán alapuló, kvalitatív módszer segítségével történt, melynek célja azon kérdések tisztázása volt, melyek a vezetés véleményét és értékítéletét hivatottak feltárni az emberi tényező fontosságának és a diszkrimináció vállalati helyzetének megítélése érdekében. Az interjú a vállalat HR-vezetôjével került lefolytatásra.

A kutatás egy nagyobb ívú további vizsgálat elôszobájának tekinthetố, mely egyfajta szondát, általános következtetések megfogalmazását tette lehetővé. Ennek következtében több fontos kérdés a vizsgálatok további fázisaiban kerül részletesebb elemzésre, és a háttérben húzódó okok feltárása, illetve szükséges vezetői intézkedések megfogalmazása is a teljes körú elemzési eredmények tükrében válik lehetôvé.

\section{A vizsgált szervezet bemutatása}

A vizsgálat tárgya egy nagy múltú bőripari vállalat leányvállalata, mely teljes egészében külföldi tulajdonnal került megalapításra, korlátolt felelősségú társasági formában. Ügyfelei között magánszemélyek és vállalatok egyaránt megtalálhatók, minden társadalmi rétegből és minden korosztályból. Elhelyezkedése logisztikai szempontból igen kedvező. A cég több mint ötszáz fónek biztosít munkahelyet. A leányvállalat szervezeti struktúrája funkcionális felépítésú, mely szolgálja a jelenlegi folyamatok sikeres múködését.

A helyi vezetés feleloós az általa irányított terület múködéséért, de a vállalat stratégiáját a külföldi anyavállalat determinálja. A vállalat indulásakor a felsố vezetés kizárólag a külföldi tulajdonos nemzetiségéból 
származott, mára már csak hazai vezetôk és alkalmazottak vesznek részt a szervezet múködtetésében. Ezzel együtt a cég megőrizte azt a szellemiséget, kultúrát, vezetôi magatartási mintákat, mely a kizárólagos külföldi vezetés jelenléte esetén is jellemző volt.

A gazdasági válság ellenére a vállalat mutatói pozitív eredményt tükröztek/nek folyamatosan, a sikerességét garantáló tényező az állandó megújulóképessége.

\section{Kutatási eredmények}

\section{A vállalati HR legfontosabb jellemzói a diszkrimináció szempontjából}

A korrekt vállalati kép kialakításához hozzátartozik a cég HR-tevékenységének rövid bemutatása, mely előrevetít bizonyos értékítéletet a munkatársak kezelésében. Az információk személyes megfigyelés és a HR-vezetővel folytatott interjú alapján kerültek összegyứjtésre.

A diszkrimináció lehetőségét leginkább magában hordozó tényezók a HR területén: az új alkalmazottak toborzási, kiválasztási eljárásai nem szabályozottak, ugyanakkor az alkalmazás szabályai összhangban állnak a Munka Törvénykönyvében megfogalmazottakkal (1. táblázat). A vállalat rendelkezik etikai kódexszel,

\section{Az alkalmazott kiválasztási módszerek}

\begin{tabular}{|c|l|c|}
\hline \multicolumn{3}{|c|}{ Kiválasztási módszerek alkalmazásának } \\
gyakorisága a vállalatnál \\
\hline Sorrend & \multicolumn{1}{|c|}{ Módszer } & $\%$ \\
\hline 1. & Önéletrajz & 65 \\
\hline 2. & Személyes interjú & 19 \\
\hline 3. & Mások által adott referenciák & 9 \\
\hline 4. & Telefonos interjú & 4 \\
\hline 5. & Dolgozói ajánlás & 3 \\
\hline Összesen & 100 \\
\hline
\end{tabular}

Forrás: saját szerkesztés a vállalat adatai alapján

és abban bár a törvényi előírásoknak megfelelően a diszkrimináció kérdései szabályozottak, konkrét esetekben még nem került sor a lefektetett magatartási szabályok számonkérésére.

Bár a HR-vezetô elmondása alapján minden törvényi előírást betartanak a HR-folyamatok megvalósításában, mégis a vizsgálatunk során e munkafázis során tapasztaltunk először diszkriminatív eljárást. A legutolsó jelentôsebb munkafázisban kizárólag férfiakat választottak.
(A betöltendő munkaköri elvárások nem indokolták ezt a döntést. Mivel utólagos információként szereztünk tudomást erról, nem állt módunkban vizsgálni ennek a jogosságát, de mindenesetre figyelemre érdemes kérdésként jegyeztük a további vizsgálatainkhoz.) Azért is figyelemre méltó ez a HR-döntés, mert általában is jellemzô hogy, néhány kivételtôl eltekintve, nôk nem kerülnek vezetôii pozícióba, pl. a felsô vezetésben egyetlen hölgy sincs. Mi ennek az oka? Az anyavállalat vállalati stratégiájában találjuk meg a választ, mely a cég egészére kihatással van. (A stratégia részletes elemzése ugyancsak késóbbi elemzés tárgya lesz.) (1. ábra)

\section{A kérdöives felmérés eredményei}

A kérdőíves felmérés eredményei közül a leginkább informatív eredményeket igyekszünk bemutatni, melyek a fentiekben megfogalmazott kutatási kérdések megválaszolását és a célkitűzésekben előirányzott elképzeléseink létjogosultságát igazolják. Ennek megfelelően a kérdőív kérdései közül válogatva a legfontosabb eredményeket a következókben tekinthetik át az olvasók.

A munkavállalók számára fontos a karrierépítés, de a nók ezen a téren alkalmat sem kapnak arra, hogy bizonyíthassák rátermettségüket (1. ábra). (A felvételi során a szóbeli interjúkon olyan kérdésekkel találkozhatunk, mely a személyes életüket érinti, és máris diszkriminációra ad okot, például házasság, gyermekvállalási szándék.

A középvezetốk szintjén tipikus nôi pozíciók a bérelszámolók és a varroda nói munkatársait irányító beosztások. Ha a nốk és a család szempontjából vizsgáljuk a vállalatot, hiányosságok egész sora vonultatható fel. A kisgyermekes munkavállalók visszatérését, visszaillesztését segító rész- és rugalmas foglalkoztatástól a szervezet vezetése elhatárolta magát, sốt túlóra igénye esetén sem veszi figyelembe az anyák kettôs szerepét. Nincsenek bölcsődei és óvodai elhelyezést biztosító
Nók és férfiak aránya a vállalat különböző szintjein

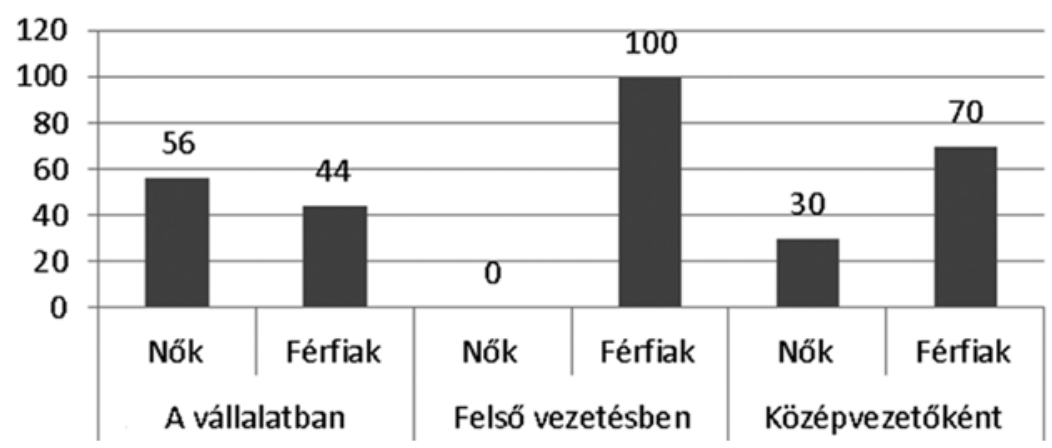

Forrás: saját szerkesztés a vállalat adatai alapján 
A vállalat korfája

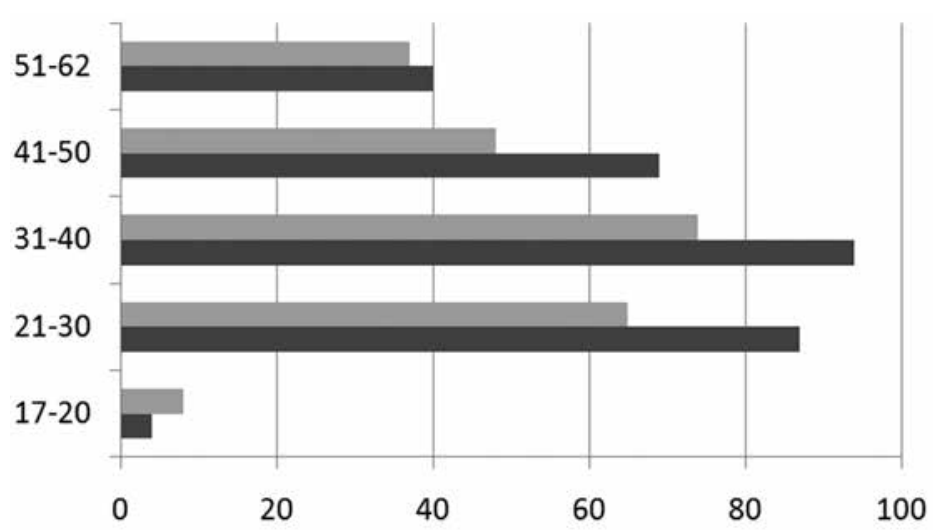

2. ábra

FÉRFIAK

nÖK

Forrás: saját szerkesztés a vállalat adatai alapján

családbarát kezdeményezések. Egyetlen pozitívumot a nyári táborozást támogató családsegítô programban véltünk felfedezni, melyet évente nyújt az igénylő́k számára.

A 2. ábra mutatja meg a szervezethez bekerülő alkalmazottak kor szerinti megoszlását. A bekerült személyek több mint 70\%-a 40 éven aluli. Ez ugyancsak diszkriminatív lépésként értékelhető. A diszkrimináció szemszögéból fontos azt is látni, férfi-e vagy nố az illetô. Ez nemcsak a fizikai és pszichikai másság miatt fontos, hanem mert a diszkrimináció két legismertebb területéből a nốk ellen irányuló megkülönböztetés a legnagyobb és legfájóbb terület.

A tendencia szerint a vállalat a 21 és 40 év közötti alkalmazottakat részesíti elônyben. Ez az érték a 65\%os túlnyomó többséget jelenti, miközben ismert tény, hogy az európai társadalmak küszködnek az elöregedés problémájával. Két veszélyeztetett korosztályt kell kiemelni: a fiatalokat és az idősödő korosztályt. A pályakezdók a legcsekélyebb, 4\%-os arányban képviseltetik magukat. Az idôsebbek 13\%-os alkalmazását több tényezővel is magyarázták. (Gyakoribb egészségügyi problémák, az idősebbek nem mindig tudnak lépést tartani a gyorsan fejlődố technikával, terhelhetốségük alacsonyabb. S vajon tényleg valósak ezek a problémák, vagy csupán előítélet?) A vállalatnál megfigyelhetô, hogy az emberek, félve az elbocsátástól, egészségügyi problémáikkal nem fordulnak orvoshoz. Gyakran betegen végzik munkájukat, s csak amikor már súlyosabb szövődmények lépnek fel, kérnek orvosi segítséget. Ez egy újabb problémát vet fel, hiszen az elhanyagolt vagy késői segítségnyújtás súlyos következményeket von maga után. (Pl., ha megfigyeljük a vállalat egészségügyi statisztikáit, kiemelten magas a vetélések és a rákos megbetegedések száma.)

A kor összetételéból adódóan kutatásunkba a legproduktívabb életkorúak kapcsolódtak be. Ez egyrészt nagyon örvendetes, mert attól a rétegtól kaphattunk információkat, akik ténylegesen aktívak, másrészt viszont pontosan a leginkább diszkriminált réteg véleményét kevésbé ismerhettük meg.

A kor problémája mellett a másik kényes és diszkriminációt jelzô vállalati értékítélet a bérek megállapítása során érhetố tetten.

Általában jellemző, hogy a nók keresete alacsonyabb, mint a férfiaké. A 3. ábra mutatja, hogy nincs ez más-

3. ábra

A bérek alakulás (euróban)

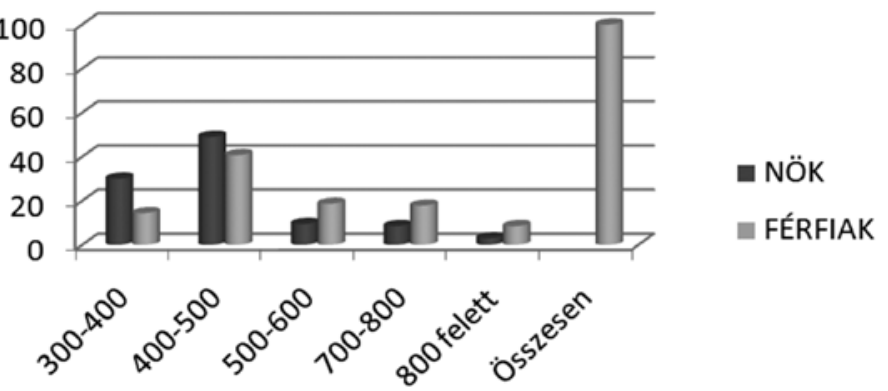

Forrás: saját szerkesztés

ként az általunk vizsgált vállalatnál sem. A legalacsonyabb bérezésú munkakörökben egyértelmúen a nók aránya magasabb. A vizsgált nốk 100\%-ából mintegy $30 \%$ tartozik ide, míg a férfiak esetében ez $14,41 \%$. Ha a két értéket vizsgáljuk, látható, hogy a nôk duplája dolgozik a legalacsonyabb bérkategóriában. A következő, ,átlagfizetés” kategóriában szintén a nốk aránya magasabb, 49\%, a férfiak 40,68\%-ához viszonyítva. És itt fordul a helyzet. Minél magasabb kategóriát vizsgálunk, annál nagyobb eltérés mutatkozik. Az utolsó elótti kategóriában a férfiak 17,8\%-a (ami több mint duplája a hölgyek számának) található ebben a szektorban a nók 8,5\%-ához viszonyítva. A legmagasabb fizetéseknél már háromszoros különbség látható. A nốk mindössze $3 \%$-a tartozik ide, míg a férfiak 8,5\%-a. Mindez egyértelmú következménye annak a vezetési irányelvnek és szervezeti kultúrának, mely a nóket nem kívánja vezetó pozícióban látni a vállalatnál.

Megvizsgáltuk, hogy van-e szignifikáns összefüggés a kor és a bérek alakulása között. A Pearson-féle Khi-négyzet próba eredménye ( 9,452 df: 1 szign.: 0,002 $\mathrm{p}<0,05)$ szignifikáns összefüggést mutatott. Az elvi feltételezés és a valós eredmények összecsengenek. 


\section{A diszkrimináció fogalmának értelmezése}

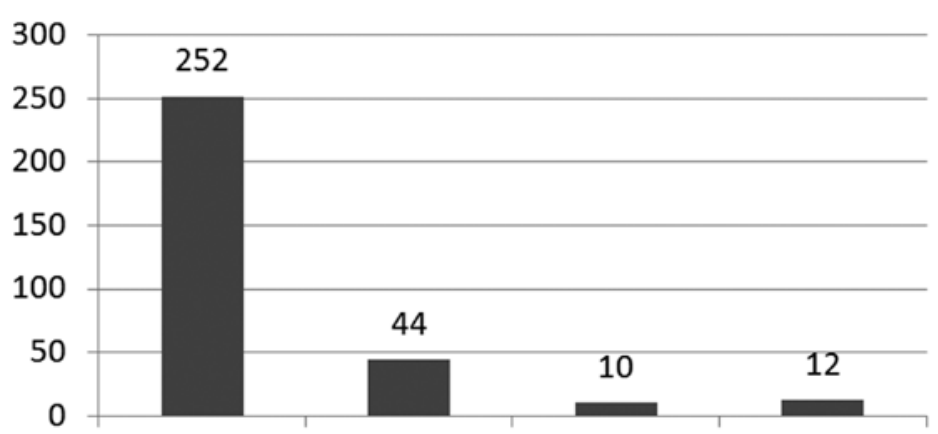

Forrás: saját szerkesztés

Kíváncsiak voltunk arra, hogy a megkérdezett emberek értik-e a diszkrimináció kifejezés mögötti tartalmat (4. ábra). A megvizsgált sokaság 79,2\%-a tökéletesen tudatában van, mit takar a kifejezés, $13,8 \%$-a részben tisztában volt vele. A fennmaradt mindössze 7\%-ot elenyészônek véltük a 93\%-os többséghez viszonyítva.

Arra a kérdésre, hogy milyen formában nyilvánulhat meg hátrányos megkülönböztetés a saját tapasztalatuk alapján, a következő lehetőségek kerültek felsorolásra:

- nem engedik elóbbre lépni a ranglétrán,

- megszüntetik vele a kapcsolatot, kirekesztik, nem beszélnek vele,

- az egyenértékú munkát kevesebbnek tekintik, alacsonyabb bérezésben részesül,

- tudatosan olyan munkavégzésre kötelezik, amely a többi kollégától elszigeteli, izolálják, ezáltal szociális kapcsolatait szüntetik meg,

- viccet úznek fogyatékosságából, vallásából, nemzetiségéból stb.,

- olyan munkák elvégzését bízzák rá, amellyel lealacsonyítják, esetleg nem kap meg egyáltalán bizonyos feladatokat,

- megvonják kompetenciáit stb.

A megkérdezettek 32\%-át saját bevallásuk szerint még nem érte munkahelyi diszkrimináció. Ezt igen kedvezónek tartjuk, különösen más multinacionális cégekhez viszonyítva. Azokat azonban, akik másképp érezték, megkérdeztük arról, hogy milyen megnyilvánulással szembesültek.

Két különösen érzékeny terület: az egyik, a 41\%-ot képviselő nókkel szemben alkalmazott hátrányos megkülönböztetés, a másik, a 22\%-ot kitevő koralapú megkülönböztetés. Magas, $17 \%$ az egyéb kategória. Néhány ok, amelyet ezen belül az érintettek megemlítettek: alaptalan pletyka, iskolai végzettség, családi érintettség, falusi volta miatt, túlságosan jól végezte a munkáját, amit mások nem jó szemmel néztek stb.
Kíváncsiak voltunk arra is, hogy van-e kapcsolat a diszkrimináció fogalom ismerete és az észlelt megkülönböztetés fajtája között. Ez esetben a Pearson-féle Khi-négyzet próba (3,078 df: 1 szign.: 0,079 p $>0,05)$ nem mutatott összefüggést.

A legnagyobb visszaélések (44\%) a munkahelyen, munkavégzés közben történtek, majd ezt követi a felvételkor történő szabálysértés, $21 \%$. A továbbképzések lehetôsége esetén fellépő igazságtalanság $15 \%$ esetében jelentett már problémát. Az előléptetés hiányát esélyegyenlőségi okra visszavezethetôen az alkalmazottak 12\%-a nehezményezi, míg a 8\%-ot képviselô egyéb kategóriában szerepel például, hogy egy családtag elbocsájtása miatt nem kapott meg egy magasabb pozíciót a válaszadó személy.

A megkérdezettek nagyobb hányada (57\%) a kollégáitól szenvedi el a megkülönböztetô magatartást, csak ezután következik a felettesektól származó probléma, 39\%-kal. Ez a diszkrimináció tényét inkább társadalmi problémaként fémjelzi.

Arra a kérdésre, hogy alkalomadtán tudatában vannak-e a jogszerútlen viselkedésnek, a következő válaszok születtek: A megkérdezettek 48\%-a csak részben volt tisztában a ténnyel, hogy felléphet a diszkrimináció ellen jogi úton, míg 43\%-uk tudatában volt. A következő kérdésben kíváncsiak voltunk arra, hogy vajon hogyan és miként cselekszenek egy ilyen helyzetben.

A válaszok kissé meglepőek voltak. Ugyanis $42 \%$-ban léptek fel az emberek az óket érô sérelem ellen. Habár azok aránya, akik szó nélkül tû́rnek, magasabb, de mindenképp meglepő azok száma, akik kiállnak magukért.

Megkérdeztük, hogy vajon, ha bármilyen módon fellépnek a sérelem ellen, milyen módját választják ennek. Azon válaszadók, akik a saját védelmükben fellépnek, a következő reakciókat adták válaszul a támadásokra.

A megkérdezettek 44\%-ban valamilyen viselkedési formán keresztül fejezték ki megbántottságukat. Ezek a reakciók kellően sokszínúek. A sértett durcás viselkedéstől a tehetetlen csapkodás, sírás is megnyilvánult. 32\%-ban választották az intelligensebb „beszéljük meg!" megoldást. Bár $12 \%$ felemlegette a jogi lehetőségeket, senki sem jutott el a tényleges hivatalos lépésekig. Tapasztalatunk szerint rendkívül kevés bírósági esetet regisztráltak a korábbiakban az esélyegyenlőség megsértésének ügyében. Ennek a hátterében legnagyobb részben a munkahely elvesztésétól való félelem áll.

Érdekes kérdés az is, hogy vajon milyen hatást gyakorol az érintettek munkavégzésére, teljesítményére a megkülönböztető bánásmód. A következő válaszokat kaptuk: 
$29 \%$ válaszolta, hogy nem befolyásolta munkavégzését és késóbbi viselkedését a diszkriminált bánásmód, és 34\% mondta, hogy bár a történtek hatása alá került, de nem engedhette meg magának, hogy teljesítménye romoljon. $15 \%$ jelezte, hogy teljesítménye érezhetôen romlott, míg 22\%-nak csak kisebb mértékben.

Mivel diszkrimináció áldozatává bárki válhat, érdemes megvizsgálni nemcsak a közvetlen munkahelyi teljesítményre gyakorolt hatását, hanem a hosszabb távon is problémákat okozó pszichológiai következményeket is. Rendelkezhet bárki határozott egyéniséggel, képes lehet megvédeni magát akár nyilvánosan is, mégsem lehetünk biztosak abban, hogy a kemény külsố mögött a lelki sérülés elmarad.

A megkérdezetteknek mindösszesen 6\%-a válaszolta, hogy érezhetóen nem hatott rá lelkileg a megkülönböztetett bánásmód. Az általunk felsorolt lehetőségeket a következố arányban jelölték az érintettek: 30\% szorongást, 24\% idegességet, míg 29\% szomorúságot érzett. Komolyabb pszichoszomatikus tüneteket $11 \%$ produkált (tikkelés, közöny, depresszió stb.).

Látható, hogy igen komoly lelki, késóbb fizikai problémákat okozhat a diszkrimináció megjelenése a munkahelyi közösségekben, ezért megkérdeztük, hogy mi az oka annak, hogy többségében mégsem kérnek jogi vagy egyéb segítséget. Az eredmény nem meglepó. Az érintettek 56\%-a munkahelye elvesztésétól, míg $35 \%$ egyéb megtorlástól tart (munkatársak bosszúja, prémium elvesztése stb.). $9 \%$ esetében érdektelenséggel találkoztunk.

Megvizsgáltuk, hogy van-e összefüggés a munkahely elvesztésétől tartó kollégák és az általuk tapasztalt lelki problémák által kiváltott jelenségek között. A Pearson-féle Khi-négyzet próba (4,208 df: 1 szign.: $0,040 \mathrm{p}<0,05)$ szignifikáns összefüggést mutatott. A kapott eredmény önmagáért beszél.

További vizsgálat tárgya lehet, hogy vajon a munkatársak egyéni érzékenysége, tưróképessége mennyire befolyásolja a tünetek megjelenését vagy a diszkrimináció jelenségének tolerálását. Ezekre a kérdésekre a lefolytatott vizsgálatból egyelőre nem tudunk választ adni, mélyebb kutatások szükségesek a továbbiakban.

A kérdőív utolsó kérdését nyitva hagytuk, és arra voltunk kíváncsiak, hogy az érintettek miben látják a diszkrimináció kiküszöbölésének lehetőségét. Az alábbi válaszok születtek, melyeket kritikai megjegyzések nélkül, nem teljeskörúen mutatunk be:

- egy munkarészlegre hasonló korú, végzettségú és életszínvonalú emberek felvétele,

- jobban oda kellene figyelni bizonyos hatóságoknak a diszkriminációra,
- sajnos nem látok rá reális esélyt, hogy a diszkriminációt kiküszöböljék,

- ne ítéljünk előre, csak akkor, ha tisztában vagyunk, milyen a másik, mire képes, milyen adottságai vannak,

- a fönök mindenkivel egyformán bánjon, mert van olyan beosztottja, akinek nem mer szólni, s így ő többet megengedhet magának,

- ha az elvégzett munkámmal bebizonyítom, hogy ha az iskolai végzettségem nem is elegendó a munkámhoz, azért még jó szakember vagyok; lehet, hogy a tapasztalataim többet érnek, mint a diplomás kollégának, aki csak az elmélet embere,

- ez hozzáállás kérdése; sajnos az emberek nem látják be, hogy mindenkiben van hiba... (tolerálni kell a másikat),

- abban, ha egy vállalat biztosan megvédené az embereket; erre nem látok egyelöre biztos jeleket, talán, ha nem hagyná, hogy meg legyenek félemlítve a dolgozók.

- nagyobb önbecsülésben és jártasságban a jogaimat illetően,

- ez sajnos az emberekbe genetikailag benne van, nagy akaraterô kell hozzá, hogy ezen tudjanak változtatni,

- pozitív kommunikáció az alkalmazottak, továbbá az alkalmazottak és a felettesek között,

- az emberek gondolkodásának megváltozása, korrupció megszúnése, munkahelyi kultúra pozitív változtatása.

\section{Összegzés}

Az Európai Unióhoz való csatlakozás feltételeként a belépó országok számára megfogalmazott szabályok alapján jogharmonizációs feladatokat kellett elvégezni. Ez komoly feladat elé állította valamennyi keletközép-európai országot. E feladatok között szerepelt az egyenlố esélyek biztosítása a különbözó társadalmi helyzetekben, életfeltételek között élő, és különböző jellemzókkel rendelkezó egyének, csoportok között a mindennapokban és a munkahelyen egyaránt.

Vizsgálatunkban teljes, átfogó képet ugyan nem kaphattunk, de a felmérés eredményei, úgy gondoljuk, húen tükrözik azt a kórképet, mely minósíti mindazt, amit sikerült elérni, és előrevetíti a még megvalósítandó feladatokat. A gazdasági növekedés, az életszínvonal emelése, a munkaerő-szükségletek kielégítésének problémája mellett a munkahelyeken fellépő diszkrimináció elhárítása méltán eltörpülni látszik. Meglátásunk 
szerint a munkahelyi egyenjogúság még várat magára. Az esélyegyenlőségi törvény számos módon kikényszeríti a vállalatokból, egyénekból a viselkedés bizonyos hivatalosan elfogadható formáit, de a társadalom szereplőit az értékek felismerésére, a szabályok betartására csak hosszú távon érvényesülő értékrendváltással, erkölcsi és etikai normák elfogadtatásával lehet rábírni. A gazdaságban jelentkezô újabb kihívásokkal egy stabil és megalapozott társadalmi normarendszer képes csak szembenézni. A diszkrimináció kiküszöbölése érdekében megfogalmazódtak a törvények, de tapasztalatunk mégis azt bizonyítja, hogy mindennapjainkban és a vállalati gyakorlatban is csak formálisan érvényesülő egyenlóséggel találkozhatunk. (Vagy még azzal sem.) A munkahelyen alkalmazott egyenlő bánásmód elve az emberi közösség minden tagját megillető egyenlố tisztelet és törődés gondolatában gyökerezik. Azonban a jog önmagában nem képes a több évszázados eloótéletek megszüntetésére.

A munkavállalókkal szemben elkövetett jogsértések túlnyomó hányada nem lát napvilágot, a diszkrimináció esetei nem kerülnek nyilvánosságra, az emberek inkább megpróbálnak túllépni az ilyen jellegú problémáikon. Ez nem jelenti azt, hogy nincsenek ilyen gondok, vagy nem kell foglalkozni velük.

A vizsgálati eredmények visszaigazolták azokat az egyébként is sokak által megtapasztalt jelenségeket, amelyek a nốk munkavállalási esélyeivel, munkahelyi elismerésével, bérezésével, karrierlehetôségeivel, a munkavállalók életkorával, nemével kapcsolatban mindennapos diszkriminatív cselekedetként érezhetünk. S hogy mégis miért nincs az ilyen rendszeresen ismétlödô problémákból jogi eljárás, ugyancsak megválaszolta a vizsgálat. Az emberek félnek, féltik a munkahelyüket, a megélhetésüket, ezért inkább csendben tû́rnek, s viselik az esetleges további fizikai és lelki problémák következményeit. A kérdés, hogy ez jól van-e így. Megéri-e a vállalatoknak az alulmotivált, depressziós, félelemtól görcsös vagy megbántottságtól befelé forduló alkalmazottakkal dolgozni, és megpróbálni teljesítményt kisajtolni? Lehetne-e mindezt másképp? Ha igen, hogyan?

A további vizsgálatainkban arra keressük a választ, hogy vajon a vállalatok vezetése érzékeli-e, és hogyan éli meg ezeket a problémákat, mit tesznek kialakulásuk ellen, s milyen sikerre számítanak ezen a területen? Akarnak-e, tudnak-e olyan közösséget és kultúrát formálni, ahol a bizalom, az etikai, erkölcsi értékek, az egymás megbecsülése domináns, és az üzleti eredmények ezeken az alapokon épülnek? További vizsgálati eredményeinkról egy következó tanulmányban adunk számot.

\section{Felhasznált irodalom}

Babusik, F. - Adler, J. (2002): Romákat foglalkoztató vállalkozások. in: A romák esélyei Magyarországon. Budapest: Kávé Kiadó - Delphoi Consulting: p. 266-324.

Debreceniová, J. - Ocenasova, Z. (2005): Monitoring law and practice in Slovakia. (on-line). Open Society Institute, 101. S. (cit. 2012.09.24.). Dostupné na internete: http:// www.opensocietyfoundations.org/sites/default/files/ eowmslovakia_2005_0.pdf

Debrecéniová, J. (2011): Antidiskriminačný zákon: Komentár. Bratislava: Občan, demokrácia a zodpovednost', dotlač 1. Vydania z r. 2008, p. 305. ISBN 978-80-89140-16-9

Debrecéniová, J. (2006): Čo/ne/vieme o diskriminácií. Bratislava: Sineal, Spol.sro. p.53 ISBN 978-80-89140-14-5

Ebtv. 2003. évi CXXV. törvény

Employment Discrimination:an overview 2013. http://www. law.cornell.edu/wex/employment_discrimination

Employment Discrimination 2008. Legal Information Center http://public.getlegal.com/legal-info-center/ employment-discrimination

Fair Work Act, Australian Government Ombudsman 2009. https://www.fairwork.gov.au/employment/discrimination/pages/default.aspx

Gyulavári, T. - Kardos, E. (2000): Egyenlóbben! A nók és a férfiak esélyegyenlősége az Európai Unióban és Magyarországon. Budapest: Indok Bt., p. 112 ISBN 963-00-4651-2

Gyulavári, T. - Könczei, Gy. (2000): Európai szociális jog. Budapest: Osiris Kiadó, p. 394. ISBN 963-379-641-5. http://www.instore.sk/news/diskriminacia-na-pracovisku

Kende, T. (szerk.) (2005): Európai közjog és politika. Budapest: Osiris, p. 888. ISBN 963-389-796-3

Kertesi, G. (2001): Munkavállalás. Perspektívák egy tágra zárt társadalomban. Konferenciakiadvány. BKÁE Társadalomelméleti Kollégium. in: Fordulat (on-line). p. 208. (2012. 09. 12.) Dostupné na internete http://ex.tek. bke.hu/perspektivak/persp_kiadv.pdf ISSN 1585-0560.

Szalai, P. (2011): Non-formal Learning Increase the Chances of Employment. in: „Advanced Learning Technologies and Applications (ALTA'2011)" címú nemzetközi tudományos konferenciakiadvány. - Vilnius, Litvánia

Szalai, P. (2011b): A nemek közti jövedelemkülönbségek három különböző felfogásban. CEO Magazin, XII. évf. 4.: p. $1-8$.

Szuhay, P. (1999): Foglalkozási és megélhetési stratégiák a magyarországi romák körében. in: Cigányok Magyarországon. Budapest: Magyar Tudományos Akadémia, p.139-160. ISBN 963-508-084-0

Štangová, v. Rovné zacházení a zákaz diskrimináce v pracovním právu. Praha: Vydavatelství a nakladatelství aleš čeněk s. R. O., 2011. p. 240. ISBN 9788073802776.

Világi, R. (2008): A szervezeti kultúra érvényesülése a szervezet létszámgazdálkodásában, (on-line). 2008. 26. (2013.04.26.) Dostupné na internete: http://www.zskf. hu/images_uploaded/4eedeaca51624.pdf 